\title{
APPRAISING INSTRUCTIONAL MATERIALS UTILIZATION IN THE COURSE OF SCIENCE TEACHING IN SENIOR SECONDARY SCHOOLS IN ZAMFARA STATE
}

\author{
ABDULLAHI NASIRU AFEES AKANNI AMUDA \\ Dept. of Science \& Vocational Education, Usmanu Danfodiyo University, Sokoto, Nigeria \\ DAHIRU A. MOH'D (Dept. of Biology, Umaru Suleiman College of Educ, Gashua, Nigeria) \\ ASHIRU SAIDU (Dept. of Biology, College of Education, Maru, Nigeria)
}

\begin{abstract}
The paper examined the rate at which instructional material is been put to use in science teaching in secondary schools in Nigeria. The paper looked at the meaning of instructional material, it utilization, some common science instructional material were also looked at, the role play by instructional material in Science teaching were also discussed. The paper looked at some major problems of science teaching as resources problems, teachers' problems which include lack of adequate professionally trained physics teachers, students' problems which include poor students' background in science and negative attitude of students towards science and government/stakeholders' problems which include poor remuneration/incentive of the science teachers, there is no effective supervision, in ad equate instructional materials. The resultant effects are increased in massive failure of science students in senior school certificate examination and negative attitude towards science. The paper therefore concludes that concern on science teaching should be judged to the extent by which the importance of science teaching is well understood by the stakeholders and the entire populace in our country. Some of the recommendations highlighted include prompt and proper remuneration of science teachers, provision of adequate instructional materials by the government/stakeholders and that governments should be organizing conferences and workshops with aims to enlightening teacher and general public on importance of science well as effective teaching of science in secondary schools.
\end{abstract}

Keywords: Appraising, Instructional Material, Utilization and Science Teaching.

\section{Introduction}

The importance of teaching with provision of adequate instructional facilities for education cannot be over-emphasized. Pertaining to the teaching of science in secondary schools, Instructional facilities include equipment and materials that are available to facilitate teaching and learning processes, this includes good laboratories, laboratory equipment/apparatus, books, audio-visual, software and hardware of educational technology (Farrant, in Abdulrahman, 2012). According to Oni in Abdulrahman (2012), instructional materials constitute a strategic factor in the functioning of a secondary school system. This is so because they determine to a very large extent the smooth functioning of any teaching and experimental demonstrations and even other extra-curricular activities. He further stated that their availability, adequacy and relevance influence efficiency and high performance. In his words, Farombi in Abdulrahman (2012) opined that the wealth of a nation or society could determine the quality of education in that land; emphasizing that a society that is wealthy will establish good schools with professional personnel (quality teachers), learning infrastructures that with such, students may learn with ease thus bringing about good academic achievement. Writing on the role of facilities in teaching, Balogun in Isola (2010) submitted that no effective science education programme can exist without equipment for teaching. This is because materials enable the learner to develop problem-solving skills and scientific attitudes. In their contribution, Ajayi and Ogunyemi in Isola (2010) reiterated that when facilities are provided to meet relative needs of a school system, students will not only have access to the reference materials mentioned by the teacher, but individual students will also learn at their own paces 
and there is room and necessary equipment for the teacher for further research and constant practice. The net effect of this is increased overall academic performance of the entire students.

In recent times, there has been a growing public anxiety about the poor performance of students in Science in Nigerian schools. Studies showed that large numbers of students seem to learn very little science at school, learning tends to be by rote and students find learning of Science to be difficult (Salau, in Isola, 2010). The quality of the personnels handling science in Nigerian schools has also been questioned over time by parents, science educators, and the general public and even by the government (Okebukola, in Adesoji, 2016). Science teaching in Nigerian schools has been criticized because of the poor performance of Nigerian students in science relative to their counterparts in other countries. This is evident from the Second International Science Study in which Nigerian students came second to last in secondary science among the participating countries of the world (STAN, in Adesoji, 2016).

\section{Conceptualization}

\section{Appraisal}

Appraisal refers to the impartial analysis and evaluation conducted according to established criterial to determine the acceptability, merit or worth of an item or situation.

\section{Instructional Material}

Anything that can facilitate teaching and learning is referred to as instructional material. Obanga (2010) defines resources as equipment which the teacher can use to help toward the achievement of lesson objectives. Isola (2010) also describes instructional materials as objects or devices that assist the teachers to present their lessons logically and sequentially to the learners. According to Umeh, (2006) resources are vital tools in education; they aid teaching and learning and include everything that provide information to the teacher as well as the learners. Umeh explained that resources included all forms of information that are used to promote, encourage and enhance teaching and learning activities. These resources can be in form of laboratory facilities, materials and humans. According to Abdullahi (2010), instructional materials are tools locally made or imported that help to facilitate the teaching/learning process.

\section{Utilization}

Utilization simply means the level to which something is put into use. Applying this to science teaching implies the level which instructional materials are used in science teaching.

\section{Science}

According to Abdullahi (1982) science is defined as activities culminating into testable, falsifiable and verifiable body of knowledge. He classified science into 
conceptual or basic science and applied or technical science. Basic science has a dual nature; it is a body of knowledge, and the process of acquiring and refining the knowledge. Examples of basic science are Biology, Chemistry and Physics. Applied or technological science on the other hand, is primarily concerned with finding solutions to practical problems. Examples are Engineering, Medicine, and so on. Mere observation of the above definition of science suggest the inquiry nature of science as it emphasis the practical nature of science since the subject cannot be meaningfully understood without the students' active participation which necessitates laboratory activities.

\section{The Problem}

The present senior secondary school science curriculum is built on the conception of science as both product and process (Onah \& Ugwu, 2010). As a process according to Onah and Ugwu (2010), the subject has to do with the skills that are called into play by scientists in carrying out scientific investigation which implies an enquiry method in the teaching and learning of science at the secondary school level. As a product, Onah and Ugwu (2010), viewed science as consisting of scientific facts, principles, laws and generalizations derived from scientific investigations.

Science has been noted and accepted as indispensable field for modern life and survival of the mankind. Science in our school curriculum is taught with a purpose and intended goals. Science is assumed to be a bedrock in technology in which man has great hopes, with some answers to numerous questions about nature. Science may be looked at as a human enterprise. It is primarily and usually connected with the finding out about the human environment (Buseri, in Abdulrahman, 2012). Inomesia in Abdulrahman (2012) sees science as "the what", "the how" and "the why" of everything happening in our environment. The essence of science teaching is to provide trained manpower in the science and technology, and also inspire students with a desire to self -improvement and achievement of excellence (Abdulrahman, 2012). The National Policy on Education (FME, 2013) states that science education shall emphasize the teaching and learning of science process and principles. This will lead to fundamental and applied research in sciences at all levels of education.

The current situation of Science teaching and learning in Nigeria is a concern to all including government and the society at large. This paper intends to address a number of problems that may need a special attention to the stakeholders. To solve these lingering problems one needs to develop a realistic picture of what is currently happening in the teaching and learning of Science in Nigerian schools and also to identify the factors that are limiting the quality of personnel training. Furthermore, one needs to develop a reasonable ideal picture for which the nation can strive towards within the existing resource limitations.

\section{Instructional Materials in Science Teaching}

Anything that can facilitate teaching and learning is referred to as instructional material. Instructional materials play a very important role in the teaching and learning process. It enhances the memory level of the students. At this time that education has spread wide and entirely, oral teaching cannot be the key to successful 
pedagogy; therefore the teacher has to use instructional materials to make teaching and learning process interesting (Cranach, 2009).

The National Policy on Education states clearly in its aims and objectives that learners should be given opportunity to acquire basic practical skills for self-reliance and employment (FME, 2013). The aim of which is to reduce the persistent unemployment problem in the nation. For effective acquisition of the practical skills and thus achievement of the objectives, adequate provision of resources (materials) for the teaching and learning of science in the Nation's Secondary Schools are inevitable. Instructional materials are print and non-print items that are rested to impact information to students in the educational process. Resources include items such as: humans, kits, textbooks, magazines, newspapers, pictures, recording videos, instructional technology (IT), to mention a few. According to Abdullahi (2010), instructional materials are tools locally made or imported that help to facilitate the teaching/learning process. Ibe (2011) views them as materials things which are used to facilitate teaching and learning. Nsofor (2012) states the important elements of behaviour that provides the base for learning theory situation which consists of all the objects, persons and symbols in the learning environment.

\section{The Role of Instructional Material Utilization in Science Teaching}

Brown, Eshiet and Nkem, (2013) summarized the role of instructional materials as follows:

It promotes meaningful communication and effective learning.

It ensure better retention, thus making learning more permanent.

It helps to overcome the limited classroom by making the inaccessible accessible.

It provides a common experience upon which late learning can be developed. They stimulate and motivate students to learn.

According to Phyllis in Stephen (2013), instructional materials possess some inherent advantages that make them unique in teaching. For one thing, they provide the teacher with interesting and compelling platforms for conveying information since they motivate learners to want to learn more and more. Also, by providing opportunities for private study and reference, the learners' interest and curiosity are increasingly stimulated. Further, the teacher is assisted in overcoming physical difficulties that could have hindered his effective presentation of a given topic. They generally make teaching and learning easier and less stressful. They are equally indispensable catalysts of social and intellectual development of the learners. Abdulrahman (2012) defines resources to include "brain, man, machine, materials, money and student" which are to be planned, organized, directed, controlled and coordinated to achieve better teaching and learning.

Abdul-Raheem (2014) acknowledged that instructional materials are such used by teachers to aid explanations and make learning of subject matter understandable to students during teaching learning process. Jekayinfa in Abdul-Raheem (2014) observed that instructional materials help teachers to teach conveniently and the learners to learn easily without any problem. They asserted that instructional materials have direct contact with all sense organs. Kochhar in Abdul-Raheem (2014) supported that instructional materials are very significant learning and teaching tools. $\mathrm{He}$ 
suggested the needs for teachers to find necessary materials for instruction to supplement what textbooks provide in order to broaden concepts and arouse students' interests in the subject. According to Josua in Abdul-Raheem (2014), instructional materials are all things that are used to support, facilitate, influence or encourage acquisition of knowledge, competency and skills.

\section{Problems of Science Teaching}

When discussing problems of science teaching, the following questions come to mind: who is to be blamed for the way science teaching turn out to be? Whose fault is it? Is it government/stakeholders fault? The following can be seen as part of problem facing science teaching.

1. Resources Problems: Most of Nigerian secondary lack teaching resources or are short of instructional material for science teaching. Computer hard/software are absent in most of our schools, where present the electricity to power it become a problem. Most of the schools have single laboratory for Science teaching while some do not even have at all. All this are some of the critical issues that are affecting the quality of science education in this country. This assertion is supported the findings of Amuda, (2015) that majority of secondary schools in Oyo state have inadequate laboratory resources.

2. Teachers' Problems: Science is a unique subject and needs unique teachers and methodology. Many writers have attributed the problems of science teaching to teachers as majority of the science teachers are not professionally trained or simply incompetent in teaching the subjects. That is, most of the teachers teaching science subjects are holders of NCE and some holders of HND in mechanical and electrical engineering. Some problems that are associated to some science teachers are inability to relate theory to practice and how to organize their classes during practical. Janet (2009), stated that the quality of education in any country depends upon the qualities of the teachers and that the stature of any people depends upon the quality of their education.

3. Students' Problems: Majority of the students had poor background or little orientation in science subjects. Some are influenced by superstitious beliefs common to their different cultures. This may lead to misconceptions, attrition and negative attitude of students towards science. Another problem of students is that of language. Some students find it difficult to comprehend what is being taught to them and some are even shy to ask question in classroom. According to Fasanya (2005), despite the potent applications of science and technology for national building, many students step aside from choosing them as their field of study.

4. Government/Stakeholders Problems: The current situation of Science teaching and learning in Nigeria is a concern to all including government and the society at large. On the side of government, there is poor remuneration/incentives of science teachers, lack of provision of adequate professionally trained science teachers, lack of laboratories/laboratories materials, lack of science instructional materials, lack of infrastructural facilities, poor provision of conducive environment for teaching and learning of sciences and lack of effective supervision of science teachers (Matazu, 2015). 


\section{Conclusion}

The paper concluded that, concern on science teaching should be judged to the extent by which the importance of science teaching is well understood by the stakeholders, the infrastructure should be made available, the various equipment also be made available that could accelerate science teaching and learning. The availability of science teachers and their support should be made and as well as the motivation and orientation given to the students. All these are factors which could lead to provision of sound and functional science education if proper step is taken towards the provision of the aforementions resources.

\section{Suggestions}

The paper put forward the following Suggestions:

1. The teacher can explore the advantage of improvisation incase the ready-made material are not available. This will go a long way in sustaining students' interest and as well lead to better retention of the lesson by the students.

2. Government/stakeholders should be recruiting professionally trained science teachers. Also should be organizing conferences with the aims to enlightening themselves on the importance of science as well as it's effective teaching.

3. Adequate and up-to date instructional materials, infrastructures and equipment of science teaching should be provided in other to meet the standards of science teaching.

4. There should be good remuneration and incentives for Science teachers to be motivated. And science clubs should be formed to enlightening and motivate students towards learning science. 


\section{References}

Abdul-Azeez, B. O. (2014). Effects of instructional materials on secondary schools students' academic achievement in social studies in Ekiti State, Nigeria. Retrieved from http://www. google.com/2017-07-10. Pdf

Abdullahi, A. (2010). Science teaching in Nigeria. Ilorin: Atoto Press. 83-87.

Abdullahi, N. M. (2016). Effects of gender Difference and physics performance of senior science Secondary school students in Maru, Zamfara State. A Seminar Paper Presented at the Department of Science Education, ABU, Zaria.

Abdulrahman, H. A. (2012). Relationship between Laboratory facilities And human resources availability on students' performance and attitude among senior secondary students in Mani Educational Zone, Katsina State. Unpublished M.Ed. Thesis, Jos. ABU, Zaria.

Abiam, P. O. \& Odok, J. K. (2006). Factors in students' achievement in different branches of achievement in Physics. Journal of Education Foundations, 4 (2): 116-121.

Adesoji, O. A. (2016). Status of human and material resources for Nigerian science and technical colleges: Issues and challenges for NTAI education. Paper presented at proceedings of 47th Annual Conference of Science Teachers Association of Nigeria, 155-159.

Amuda A. A. (2015). Laboratory resource factors and frequency of practical as correlates of secondary students' achievement and interest in Physics in Oyo State Nigeria. ATBU Journal of Science and Technology Education, 3 (2).

Brown, L.; Eshiet, L. T. \& Nkem, B. A. (2013). The Use of instructional materials in the teaching of science as fundamental of education technology. Lagos: Johns Lod Publisher Ltd, Lagos.

Cranach, L. M. (2009). Teaching tools of teaching in the secondary school. New York: Macmillan publishing Co. Inc.

Fasanya, A. G. (2005). Physics students' cognitive preference and achievement in electromagnetism. Unpublished M. Sc. Thesis, Jos: University of Jos.

Federal Ministry of Education (2013). National Policy on Education. Lagos: NERDC Press.

Ibe, C. L. (2011). "How Nigeria teacher selects instructional materials". British Journal of Educational Technology, 19 (23): 210-2013. London: Reeding University.

Isola, O. M. (2010). Effects of standardized and improvised instructional materials on students' academic achievements in secondary school physics. M. Ed Thesis, University of Ibadan, Ibadan. 
Ivowi, U. M. O. (2009). Promoting physics education among females in Nigeria: Perspectives on education and science teaching, 135: 168-174. Abuja: Foremost Educational Services.

Ivowi, U. M. O. (2011). Promoting physics education among females in Nigeria. Abuja: Foremost Educational Services, 168 - 174.

Janet, E. O. (2009). Research methods and statistics in education and social science. Joja Educational Research and Publishers, Lagos.

Nsofor, C. C. (2012). Human resources development in science technology and mathematics education: The bedrock for sustainable development in Africa. Retrieved from http://www. stan.org.ng/journals/ 2017-03-21. Pdf

Obanga, (2011). Teaching integrated science effectively. Onisha, Nigeria: Space Matrix Publications Ltd.

Ogunleye, A. (2001). Girls' perception of strategies for improving low enrolment, under-achievement, and attitude of girls in physics at the senior secondary level. In O. O Busari (Ed.). 42nd Annual Conference Proceedings of the Science Teachers' Association of Nigeria. Ibadan: Heinemann Educational Books (Nigeria). Plc, 344-357pp.

Onah, D. O. \& Ugwu, E. I. (2010). Factors which predict performance in secondary school physics in Ebonyi North Education Zone of Ebony State, Nigeria. Advances in Applied Science Research, 1 (3): 255-258.

Stephen, E. W. (2013). Effect of use of instructional materials on learner participation in science classroom in preschool in Kiine Zone, Kirinyaga County Kenya. Retrieved from http://www. google.com/ 2017-07-11. Pdf

Umeh, O. M. (2006). Availability and use of human and material resources in teaching of ecology and genetics in Biology Education in Senior Secondary schools in Anambra State. Retrieved from http://www.stan.org.ng/journals/ 2017-05-16. Pdf

Yemisi, S. E. (2008). Teaching Science in Secondary schools. African Culture International Centre Kefu, Lagos, Nigeria. 